\title{
In the New Normal: Students' Perception and Experiences on the Shift to Flexible Learning System During the Covid-19 Pandemic
}

\author{
Dirb Boy O. Sebrero, ${ }^{1, A B C}$, Noel C. Alamin ${ }^{2, \text { DEFG }}$
}

\author{
${ }^{1}$ Masters in History, Instructor, La Salle University, Ozamiz City, Philippines. \\ Author's Contribution: ABCDEFG (A - Study design; B - Data collection; C - Data interpretation \\ ${ }^{2}$ Masters in Political Science and History, Bachelor of Laws, Political Science Department Head, La Salle University, Ozamiz City, \\ Philippines \\ Author's Contribution: - E - Manuscript preparation; F - Literature search
}

Received: 22 Dec 2021; Received in revised form: 03 Feb 2022; Accepted: 14 Feb 2022; Available online: 22 Feb 2022 (C)2022 The Author(s). Published by Infogain Publication. This is an open access article under the CC BY license (https://creativecommons.org/licenses/by/4.0/).

\begin{abstract}
This study aims to identify the way La Salle University managed in providing quality education during the Coronavirus Pandemic when Universities had little to almost no time to adapt to the abrupt changes in the educational processes from traditional face-to-face set-up to flexible online learning. Using a semi-structured questionnaire through a Google Form Survey, the researchers look into the students of La Salle University particularly on their perception, and their lived experiences regarding the flexible online distance learning, highlighting their ability to retain information, and lesson content, and their effectivity of the utilization of online platform as a tool to achieve quality education. Data collected provide an undeniable challenge that the learners experience in the course of a year in the flexible online distance learning set-up. Such challenges include but are not limited to technical issues in their access to online platforms, technical skills of teachers and instructors alike, the communication between students and teachers, and the inappropriate teaching methods used in a flexible online distance setup. Biggest emphasis on the challenges lies on the poor communication between the instructors and the learners. Based on these data, implications for the use of the universities doing flexible online learning setup, and others, are presented.
\end{abstract}

Keywords - Tertiary Education, Flexible Online learning, Covid-19 Pandemic, Students' lived experiences.

\section{BACKGROUND}

Since the start of the Covid pandemic, several developments in the factors of society have been observed. One sector which felt the biggest blow made by the pandemic is educational institution. The pandemic since has forced shifts in the educational process, especially in tertiary education which challenged the relationship and the communication between the learner and teacher. As an ongoing result of the pandemic, higher education institutions were forced to shift its old ways of providing quality education from face to face traditional set-up to a distanced flexible learning method [1]. This, coupled with the government agencies' efforts of containing the spread of the virus, assures the continued access to quality education, as universities and colleges, here and abroad, have shift to a flexible learning system [2].

Extensive literatures show that online learning provides benefits for students such as providing a student-centered education, flexibility to the hours of the students, and that online flexible learning develops interaction with the students by doing both synchronous and asynchronous tools such as e-mail, chats, video call and conferences [3]. 
In addition, technological developments that can facilitate learning provides the necessity of distributing content simultaneously to large number of students and participants. Online learning platforms also ensures that content production and distribution are easily controlled, and is easily flexible to fit to the learners' capacity, needs, paces, and the general objective of learning [4]. All these lead to better ways of communicating to students despite the disparity of internet stability, and the inherent challenges brought by the pandemic in general. In many ways, these advantages prove that flexible distanced learning can better the learning process and experience of both the students and the teachers.

However, considering the advantages that the flexible online learning brings, one cannot deny the several disadvantages that the method also creates. Flexible online learning brings elements that may challenge the learning process of the students [5]. These challenges include but are not limited to the decreased focus and motivation of the students in learning, delayed teachers' feedbacking and assistance to the students' learning, the isolated feelings of the students due to not being physically present to their classmates, and the undeniable fact that teachers may not be available and accessible whenever in need by the learners [6]. Fortunately, these challenges can be resolved with the teachers' capability to adapt to the different needs of the students [7].

To do this, it is necessary for teachers to have adept capacity ranging from the prerequisite knowledge in content and in tools, and the equivalent experience to teach in an online educational environment [8]. Hence, in an all online flexible set-up where learning takes place in an online environment, these disadvantages and disparities can be most observed. In a research published by School Education Gateway, almost $70 \%$ of the research participants who were all teachers revealed that they're all first - timers in using online platforms in providing quality education. The study then concluded a least percentage of learning by students. The study even inferred that the result can be attributed to the fact that teachers and students alike are not at all equipped in an online flexible education [9].

In an online set-up, both the academic faculty members and administrators, teachers, and students are all challenged across many reasons in an online educational environment. The United State of America's Organization for Economic Co-operation and Development states that universities are challenged in maintaining the balance between the online courses, which could highly affect the students' physical and mental health, and monitoring and managing the students' access to digital tools for learning and stable internet connectivity which may also positively or negatively their level of educational participation and learning [10]. Another challenge that universities may face takes toll on the delivery and quality of the content provided for the students. Universities are struggling to maintain the relevance and consistence of the course content, in communicating with the stakeholders of the community, and on marketing [11].

Taking into consideration the arguments mentioned above, the shift from a traditional face to face set-up in providing quality education towards a flexible online learning can have a massive influence on the students' learning process and their perception on the utilization of an online environment in the learning and teaching process. These arguments are the core of this study. The researcher considers the importance, relevance, and the necessity to analyze the students' level of adaptability to flexible online learning and their degree of satisfaction in the course of their learning in an flexible online setup.

\section{The aim of the study:}

This study aims to establish the perception of the students of La Salle University - Ozamiz in an online learning setup, especially their experiences, during the Coronavirus pandemic. This study further examines the process of learning and how it has been influenced by the pandemic and highlight the students' perception of their utilization of online platforms and how these platforms aided in their learning process. Finally, this study also identifies the issues that students experience though the course of their online learning setup, and in which better way these online learning platforms can be utilized by university administrators in providing quality education.

This study can be significant in contributing to the development and better utilization of online learning platforms in assisting learners in their learning process. This study provides information covering the useful methods of using online learning tools in delivering course content, the duration of time students need to complete their projects, and assessments as perceived by the students.

\section{MATERIALS AND METHODS}

The majority of the examinations recently referenced feature various perspectives identified with the experience of understudies and instructors in the setting in which flexible online learning and certainly, E-learning stages were utilized as correlative apparatuses to the conventional learning measure. Notwithstanding, there are a couple of studies that notice the selective utilization of E-learning stages, as it occurred during the pandemic when colleges 
had to utilize it and carry out it as a fundamental apparatus in the instructive cycle. This examination expects to outline understudies' discernments in regards to only flexible online learning through the E-learning stages, in one of the nations that had little involvement with this cycle before the pandemic.

Past to the pandemic, in La Salle University's education framework, the utilization of E-learning stages was scant. This is due to many factors such as that not many instructors were utilizing the stage, and they were chiefly utilizing its essential capacities like transferring course material. The pandemic astonished a large portion of the instructors yet additionally understudies, who were exceptionally new to internet learning stages, by compelling them to move, in an extremely brief time frame, from customary figuring out how to solely flexible online learning. In this way, the researcher led an online survey to inspect understudies' discernments in regards to the capacity of colleges to give information with regards to solely web-based learning and to analyze their disposition towards flexible online learning. In this study, the following research questions were addressed:

1. What is the perception of students about the way La Salle University managed to provide knowledge in the context of flexible online learning?

2. What are the experiences of the students about their ability to learn and assimilate information in the context of flexible online learning?

3. What are the interventions and actions made by the University Administrators to help the students with their experiences?

The population for the study was selected in a nonprobabilistic way and was comprised of 42 students and 9 Administrators of La Salle University - Ozamiz. The majority of respondents are female, mostly up to 21 years old (Table 1). However, $6(22.6 \%)$ of the students were male and 19 female $(77.4 \%)$.

Table 1. Sociodemographic characteristic of respondents.

\begin{tabular}{|l|l|l|l|}
\hline Variables & Category & Count & Percentage \\
\hline Gender & Female & 39 & $77.4 \%$ \\
& Male & 12 & $22.6 \%$ \\
\hline Degree & Bachelor & 42 & $82.2 \%$ \\
& Master & 9 & $17.8 \%$ \\
\hline Age & $18-21$ years & 42 & $82.2 \%$ \\
& $25-$ above years & 9 & $17.8 \%$ \\
\hline University & La Salle & 51 & $100 \%$ \\
& University - & & \\
\hline
\end{tabular}

Data was collected online. The questionnaire was sent as a link on the Facebook pages of the two universities through the free application Google Forms, during the second semester of the 2020-2021 academic year. The participants in the study received information at the beginning of the questionnaire about the purpose of the survey and the informed consent. Checking a specific box, they approved the participation to the study. The e-mail addresses were not collected in order to respect anonymity and confidentiality. The average time needed to answer the questionnaire was $15 \mathrm{~min}$.

\section{RESULTS}

1. What Is the Perception of Students about the Way Universities Managed to Provide Knowledge in the Context of Exclusively Online Learning?

Teachers lacked the essential technological abilities and were unable to adjust their teaching style or appropriately connect with students in an online setting in a timely manner in order to maintain strong teaching standards. Teachers' technical skills are demonstrated by their ability to use various functions provided by the E-learning platform in order to adapt their teaching style to the online environment, such as using the video conference function, in which students can actively participate because teachers can make them moderators.

These technical skills also include the ability to present topics via screen sharing, to use synchronous chat during presentations, to allow students to work in groups during seminars, to post various links on the platform with references to various sources of information, and to create and post short videos for specific laboratories/seminars. As a result, some teachers were able to find solutions, while others were unwilling to put in the effort to learn how to teach online. As a result, 86.4 percent of students said that professors only used a small number of the E-learning platform's tools: they used only the basic tools which were almost mandatory for conducting the courses, and $30.6 \%$ of students declared they have used such instruments (Table 2).

Furthermore, $15 \%$ of students said that teachers lacked the requisite abilities and that they were not motivated to enhance their teaching skills in an online setting in response to the open question. Furthermore, 22.5 percent of students stated that the biggest challenge they faced was a lack of adaptation of the teaching style to the online environment, which hampered their ability to integrate and comprehend the contents covered in the courses. In terms of the courses, 32.8 percent of respondents stated that the timetable was not adhered to: professors did not provide 
breaks, and sessions did not begin or conclude at the scheduled times.

It is crucial to strike a balance between theory and practical work, as well as allocating activities according to the amount of time available to students, in order for the teaching process to go smoothly online. As a result, 71.4 percent of students stated the courses had too much theory

Table 2. Frequency distribution of indicators related to students' perception of the use of the E-learning platform.

\begin{tabular}{|l|l|l|}
\hline Variables & Category & Percentage \\
\hline Previous experience & Previous use of the E-learning platform & $66.1 \%$ \\
\hline $\begin{array}{l}\text { The degree of use of the E- } \\
\text { learning platform }\end{array}$ & $\begin{array}{l}\text { Frequently and very frequently use of at least 7 } \\
\text { of the } 11 \text { tools evaluated }\end{array}$ & $86.4 \%$ \\
\hline $\begin{array}{l}\text { The usefulness of the E- } \\
\text { learning platform }\end{array}$ & $\begin{array}{l}\text { People who considered useful and very useful at } \\
\text { least 7 out of the 11 instruments evaluated }\end{array}$ & $68.9 \%$ \\
\cline { 2 - 3 } & Use of tools that involve collaborative learning & $30.6 \%$ \\
\hline Intention to use & Preference for the E-learning platform & $28.6 \%$ \\
\hline
\end{tabular}

On the other hand, pupils who claim they have a lot more time than they used to since their professors don't ask for their attention or engage with them as much as they used to say they do. This is supported by the responses to the open-ended question, in which $8.8 \%$ of students stated that the biggest issue was a lack of balance between prescribed activities and the time teachers offered to complete them.

\section{What Is the Perception of Students about their Ability to} Learn and Assimilate Information in the Context of flexible Online Learning?

Despite the fact that the majority of students $(66.1 \%)$ had utilized the E-learning platform before to the pandemic, their views on using the online environment for learning are mixed. Some of them $(37.4 \%)$ believe it is an adequate learning environment, while others (32\%) believe it is not. A third is uncertain $(30.6 \%)$. When it comes to their

Table 3. Frequency distribution of indicators related to student's ability to assimilate and learn while learning online

\begin{tabular}{|l|l|l|}
\hline Variables & Category & Percentage \\
\hline Interaction with teachers & $\begin{array}{l}\text { Live answer in a video conference } \\
\text { Offering an answer on chat/forum }\end{array}$ & $\begin{array}{l}43.2 \% \\
52.4 \%\end{array}$ \\
\hline $\begin{array}{l}\text { Presentation of seminar } \\
\text { projects/exercises online }\end{array}$ & $\begin{array}{l}\text { It is harder } \\
\text { It is easier } \\
\text { It is the same }\end{array}$ & $4.5 \%$ \\
\hline $\begin{array}{l}\text { Processing information is } \\
\text { easier when }\end{array}$ & $\begin{array}{l}\text { The course is carried out audio } \\
\text { The course is carried out audio and video } \\
\text { The course is carried out on the chat/forum }\end{array}$ & $32.9 \%$ \\
& $33.3 \%$ \\
\hline
\end{tabular}




\begin{tabular}{|l|l|l|}
\hline $\begin{array}{l}\text { Compared to offline teaching, } \\
\text { online information processing } \\
\text { is }\end{array}$ & $\begin{array}{l}\text { Easier } \\
\text { Harder } \\
\text { The same }\end{array}$ & $\begin{array}{l}11.9 \% \\
60.5 \% \\
27.6 \%\end{array}$ \\
\hline $\begin{array}{l}\text { General opinion towards } \\
\text { learning in the online } \\
\text { environment }\end{array}$ & Dissatisfied & Neither satisfied nor dissatisfied Very satisfied + satisfied \\
\hline $\begin{array}{l}\text { The online environment is } \\
\text { appropriate for learning }\end{array}$ & Very little extent + little extent & $29 \%$ \\
& Neither little nor great measure & $31.9 \%$ \\
& Very great extent + great extent & $32 \%$ \\
\hline Preference for online learning & $\begin{array}{l}\text { Would choose the unfolding online courses Would } \\
\text { choose the unfolding of face to face courses }\end{array}$ & $30.6 \%$ \\
& $\begin{array}{l}\text { Would choose a combination between the online and } \\
\text { offline courses }\end{array}$ & $37.4 \%$ \\
\hline & & $40.6 \%$ \\
\hline
\end{tabular}

\section{Students' Perception of the Use of E-Learning Platform}

According to the Technology Acceptance Model (TAM), the perceived ease of use of the platform's instruments, as well as the perceived utility of those instruments, impact real platform utilization. In this regard, it's worth noting that no student remarked that the platform was difficult to use in response to an open question concerning challenges faced when using it. As a result, 66.1 percent of students have used the platform before and had no trouble utilizing or manipulating the instruments it offers.

Teachers were required to utilize only the university's Elearning platform in the wake of the Coronavirus epidemic. Alternative platforms were only allowed to be used to quickly resolve technical difficulties that developed as a result of the servers hosting the E-learning platform. The majority of teachers used a considerable number of Elearning technologies (above 7) on a regular basis (86.4 percent of students mentioned this aspect). However, a lesser majority of students (68.9\%) thought at least seven of the eleven tools were beneficial.

Despite the fact that the E-learning platform passes the fundamental criteria for students to choose it (easy of use, utility), students still prefer alternative platforms due to the limited number of technical difficulties they encountered while using them. Unfortunately, students equated technical concerns with the platform's capacity, ignoring the distinction between the platform's use/utility and the capacity of the servers hosting it at the moment. As a result, only 28.6 percent of respondents would use an Elearning platform to complete course-related tasks, with the majority of these students enrolling in Bachelor's degree programs $(2(1)=4.13, p=0.04)$. (Table 6). Furthermore, while usage of the platform's instruments was lower in secondary education programs (Master programs) $(\mathrm{t}(760)=2.29 . \mathrm{p}=0.02)$, impression of the platform's utility was consistent regardless of study program level (Bachelor or Master programs) $(\mathrm{t}(760)=$ 0.33. $\mathrm{p}=0.74)$.

\section{DISCUSSION}

This study highlights two important changes in La Salle University's higher education system during the crisis caused by the Coronavirus pandemic: digitalization and the shift to a student-centered E-learning process, both of which took place in a very short period of time. Professors were pushed to move to a more student-centered sort of teaching as a result of digitalization, as E-learning platforms encourage this sort of teaching/learning [25]. Previous research has shown that when utilized as a supplement to the traditional educational process, online learning platforms help pupils [7]. Furthermore, the majority of the research cited suggest that students have generally good attitudes regarding online learning [33-35], despite the fact that they occasionally face technological difficulties and believe that they process knowledge better in traditional courses [36]. Other studies have found that online learning has a number of advantages, including improved information assimilation [49,50], adapting courses to students' needs [22], flexibility [50], student centeredness [55], and removing the barriers of space and time, all of which encourage students to participate in discussions and exchange opinions [52].

The quality of the educational process in the online environment depends on multiple factors, among which are: the level of training that teachers have in using technology, their teaching style, interaction with students, 
strategies used to capture students' attention, encouraging contact between students and faculty, collaborative learning, quick feedback, active learning, task time-encouraging students to allocate more time for completing tasks, high expectations-the teacher should communicate their expectations in order to encourage and motivate students, diversified learning, and technology application [26,27,48]. The research looked into how professors from La Salle University higher education institutions managed to offer information throughout the Coronavirus epidemic, taking these factors into account. Simultaneously, , this study puts its focused on examining students' perceptions of their experiences during solely online learning, as well as the effects this style of learning had on their capacity to acquire and absorb information.

The current study reveals that when learning solely online, several of the previously described benefits and advantages become less valuable, while negatives become more obvious. Students who answered to our survey feel that only online learning has no favorable impacts on integrating and processing knowledge, that studying and staying focused online is more difficult, and that teaching is similarly more challenging. Furthermore, students believe that presenting seminar work online is more difficult, and that they lack the bravery to speak up for fear of being criticized or ridiculed. It's also noteworthy to note that, despite the fact that students used to actively participate in offline seminar activities, very few have the bravery to express their ideas or write on the forum since they feel more exposed online.

In terms of the drawbacks of online learning, our findings are consistent with those of earlier research [54,56,57]. Students often become distracted and lose attention as a result of teachers' lack of well-implemented tactics to keep students engaged, as well as their lack of expertise with this sort of learning. In addition to these factors, environmental disruptors such as noise from family or neighbors, as well as a lack of suitable working space, have an impact on the length of time pupils can focus when studying online. Isolation is another drawback identified by our research. Students feel isolated as a result of a lack of engagement, particularly with professors, as well as the fact that they spend more time inside, in front of the internet, and as a result of the pandemic, which led individuals to socially remove themselves from others.

Other research $[37,38]$ have found that students believe the online educational process is of lower value than the conventional method, and that they prefer to use Elearning platforms in conjunction with conventional, faceto-face teaching/learning. Furthermore, students perceive that the online setting makes learning and digesting knowledge difficult, which might lead to lower learning results. Because respondents reported poor absorption of material, especially when taking more challenging courses with professors who were not well fitted, our study suggests that online learning can have an impact on students' performance. Furthermore, our findings reveal that universities are not yet ready to deploy only online teaching and learning, which is similar with the findings of previous studies [61], with inadequate interaction with instructors being one of the primary difficulties raised by students in prior studies $[9,11]$.

The hierarchy of reasons why students are hesitant to learn online is altering in the light of the pandemic-induced catastrophe. The most commonly mentioned issues were technical issues, which played a significant influence in lowering students' motivation. Another key cause is teachers' lack of technical abilities, which reflects the findings of other research done during the crisis [7]. The second reason is a misalignment of the teaching style to the online environment, and students indicated inadequate communication and contact with professors as the last argument. These latter two causes arose from a lack of technological capabilities on the one hand, and the resilience to change and lack of flexibility of certain teachers to adapt in order to appropriately offer information in the online environment on the other side.

All of these factors were mirrored in students' perceptions of the online educational process' quality, with the overall score scale indicating modest results: an average level of satisfaction. Although some studies show that students have a good attitude about entirely online learning during the crisis [58], the findings of our study are in accord with recent studies on students in Eastern Europe [64], which show that students have a negative attitude toward online learning. However, despite all of the issues, the overall score scale's medium levels for satisfaction with entirely online learning suggest that students, despite all of the issues, are satisfied. When both instructors and students were forced to cope with a circumstance they had never experienced before, especially Master students, they were able to tie these challenges to the setting of the epidemic. Thus, despite the technological issues, some professors attempted to learn, discover answers, provide assistance for students, and adjust their teaching style to the new circumstances, which some students liked.

Given the limited time frame in which instructors had to adjust to new teaching settings, the majority of them were able to meet the obstacles successfully, but there is still space for growth. Our findings suggest that the educational process was teacher-centered rather than student-centered, and that when an attempt was made to adopt a more 
student-centered procedure, pupils felt too much pressure owing to the daunting quantity of activities they were needed to complete. Students are given more duties and duties in a student-centered educational process, but since they are not used to this form of learning, they feel pressurized, and are more likely to acquire unfavorable attitudes toward online teaching and learning. Professors employed a variety of methods to make online courses more appealing, but feedback from students was occasionally delayed, tasks were not succinct, and teachers sometimes failed to convey clearly their expectations. The conventional approach in which professors used to offer the practical component of the course was no longer fit for the online setting, which is why the online educational process experienced so many challenges. Teachers produced confusion and doubt among pupils because they were unable to quickly react and come up with answers.

The relationship between students and teachers is another significant topic that should be covered. Students were affected by a lack of engagement with both instructors and classmates, according to our results. Except on rare occasions, in small groups, and during times when the server was not overburdened, E-learning systems were unable to enable video-conferences. Students, on the other hand, valued video conferences because they allowed them to avoid having to connect physically with their instructors and peers. By assigning team assignments and even using collaborative teaching technologies, some teachers were able to substitute face-to-face engagement.

When it comes to students' perceptions of the E-learning platform, most students regard it as a valuable tool for online teaching and learning. Students would prefer to utilize alternative platforms because of technical challenges caused not by the platform but by the servers of the universities that hosted it. Students prefer systems that allow numerous users to video converse for longer periods of time and that do not have as many technical issues, allowing them to engage with their professors more easily.

The desire to utilize E-learning platforms is impacted by the perceived simplicity of use and utility of the tools supplied by the platforms, according to the Technology Acceptance Model (TAM) [28]. In this context, our findings show that students had no problems using the tools provided by the E-learning platform, since they were intuitive and simple to use. Despite the fact that the evaluated instruments had a high overall score on a scale of usefulness in the learning process, only $28 \%$ of students would prefer to use these platforms because of the technical issues they caused (issues such as signal loss, unclear sound, delayed viewing of the messages, that appeared because of the servers that were hosting it, because of the large number of students that were connected). In this regard, it is suggested that colleges adopt solutions to address these concerns, because if these challenges remain, students may lose interest in participating in the educational process.

As a result, our findings demonstrated that, contrary to what previous studies claim [28-30], perceived ease of use and perceived utility alone are insufficient to motivate students to adopt E-learning platforms. Our findings imply that the Technology Acceptance Model (TAM) may be enhanced by factoring in various external elements such as university technical circumstances, students' technical circumstances, teachers' teaching style, teachers' technical capabilities, and student-teacher interaction via the platform. If the TAM model can explain the intention to use E-learning platforms in the context in which the platform is used as a complementary tool for the traditional educational process, an improved version of the model could explain the intention to use it in the context of exclusively online learning.

Professors were pushed to move to a more studentcentered sort of teaching as a result of digitalization, as Elearning platforms encourage this sort of teaching/learning [25]. Previous research has shown that when utilized as a supplement to the traditional educational process, online learning platforms help pupils [7]. Furthermore, the majority of the research cited suggest that students have generally good attitudes regarding online learning [33-35], despite the fact that they occasionally face technological difficulties and believe that they process knowledge better in traditional courses [36]. Other studies have found that online learning has a number of advantages, including improved information assimilation [49,50], adapting courses to students' needs [22], flexibility [50], student centeredness [55], and removing the barriers of space and time, all of which encourage students to participate in discussions and exchange opinions [52].

The quality of the educational process in the online environment depends on multiple factors, among which are: the level of training that teachers have in using technology, their teaching style, interaction with students, strategies used to capture students' attention, encouraging contact between students and faculty, collaborative learning, quick feedback, active learning, task time-encouraging students to allocate more time for completing tasks, high expectations-the teacher should communicate their expectations in order to encourage and motivate students, diversified learning, and technology application $[26,27,48]$.

The researcher examined how professors from La Salle University managed to offer information throughout the 
Coronavirus epidemic, taking these factors into account. Simultaneously, this study puts its focused on examining students' perceptions of their experiences during solely online learning, as well as the effects this style of learning had on their capacity to acquire and absorb information. The current study reveals that when learning solely online, several of the previously described benefits and advantages become less valuable, while negatives become more obvious. Students who answered to our survey feel that only online learning has no favorable impacts on integrating and processing knowledge, that studying and staying focused online is more difficult, and that teaching is similarly more challenging. Furthermore, students believe that presenting seminar work online is more difficult, and that they lack the bravery to speak up for fear of being criticized or ridiculed. It's also noteworthy to note that, despite the fact that students used to actively participate in offline seminar activities, very few have the bravery to express their ideas or write on the forum since they feel more exposed online.

In terms of the drawbacks of online learning, our findings are consistent with those of earlier research [54]. Students often become distracted and lose attention as a result of teachers' lack of well-implemented tactics to keep students engaged, as well as their lack of expertise with this sort of learning. In addition to these factors, environmental disruptors such as noise from family or neighbors, as well as a lack of suitable working space, have an impact on the length of time pupils can focus when studying online. Isolation is another drawback identified by our research. Students feel isolated as a result of a lack of engagement, particularly with professors, as well as the fact that they spend more time inside, in front of the internet, and as a result of the pandemic, which led individuals to socially remove themselves from others.

Other research has found that students believe the online educational process is of lower value than the conventional method, and that they prefer to use E-learning platforms in conjunction with conventional, face-to-face teaching/learning. Furthermore, students perceive that the online setting makes learning and digesting knowledge difficult, which might lead to lower learning results. Because respondents reported poor absorption of material, especially when taking more challenging courses with professors who were not well fitted, our study suggests that online learning can have an impact on students' performance. Furthermore, our findings reveal that universities are not yet ready to deploy only online teaching and learning, which is similar with the findings of previous studies [61], with inadequate interaction with instructors being one of the primary difficulties raised by students in prior studies $[9,11]$.
The hierarchy of reasons why students are hesitant to learn online is altering in the light of the pandemic-induced catastrophe. The most commonly mentioned issues were technical issues, which played a significant influence in lowering students' motivation. Another key cause is teachers' lack of technical abilities, which reflects the findings of other research done during the crisis [7]. The second reason is a misalignment of the teaching style to the online environment, and students indicated inadequate communication and contact with professors as the last argument. These latter two causes arose from a lack of technological capabilities on the one hand, and the resilience to change and lack of flexibility of certain teachers to adapt in order to appropriately offer information in the online environment on the other side.

All of these factors were mirrored in students' perceptions of the online educational process' quality, with the overall score scale indicating modest results: an average level of satisfaction. Although some studies show that students have a good attitude about entirely online learning during the crisis [58], the findings of our study are in accord with recent studies on students in Eastern Europe [64], which show that students have a negative attitude toward online learning. However, despite all of the issues, the overall score scale's medium levels for satisfaction with entirely online learning suggest that students, despite all of the issues, are satisfied. When both instructors and students were forced to cope with a circumstance they had never experienced before, especially Master students, they were able to tie these challenges to the setting of the epidemic. Thus, despite the technological issues, some professors attempted to learn, discover answers, provide assistance for students, and adjust their teaching style to the new circumstances, which some students liked.

Given the limited time frame in which instructors had to adjust to new teaching settings, the majority of them were able to meet the obstacles successfully, but there is still space for growth. Our findings suggest that the educational process was teacher-centered rather than student-centered, and that when an attempt was made to adopt a more student-centered procedure, pupils felt too much pressure owing to the daunting quantity of activities they were needed to complete. Students are given more duties and duties in a student-centered educational process, but since they are not used to this form of learning, they feel pressurized, and are more likely to acquire unfavorable attitudes toward online teaching and learning. Professors employed a variety of methods to make online courses more appealing, but feedback from students was occasionally delayed, tasks were not succinct, and teachers sometimes failed to convey clearly their expectations. The conventional approach in which professors used to offer 
the practical component of the course was no longer fit for the online setting, which is why the online educational process experienced so many challenges. Teachers produced confusion and doubt among pupils because they were unable to quickly react and come up with answers.

The relationship between students and teachers is another significant topic that should be covered. Students were affected by a lack of engagement with both instructors and classmates, according to our results. Except on rare occasions, in small groups, and during times when the server was not overburdened, E-learning systems were unable to enable video-conferences. Students, on the other hand, valued video conferences because they allowed them to avoid having to connect physically with their instructors and peers. By assigning team assignments and even using collaborative teaching technologies, some teachers were able to substitute face-to-face engagement.

When it comes to students' perceptions of the E-learning platform, most students regard it as a valuable tool for online teaching and learning. Students would prefer to utilize alternative platforms because of technical challenges caused not by the platform but by the servers of the universities that hosted it. Students prefer systems that allow numerous users to video converse for longer periods of time and that do not have as many technical issues, allowing them to engage with their professors more easily.

The desire to utilize E-learning platforms is impacted by the perceived simplicity of use and utility of the tools supplied by the platforms, according to the Technology Acceptance Model (TAM) [28]. In this context, our findings show that students had no problems using the tools provided by the E-learning platform, since they were intuitive and simple to use. Despite the fact that the evaluated instruments had a high overall score on a scale of usefulness in the learning process, only $28 \%$ of students would prefer to use these platforms because of the technical issues they caused (issues such as signal loss, unclear sound, delayed viewing of the messages, that appeared because of the servers that were hosting it, because of the large number of students that were connected). In this regard, it is suggested that colleges adopt solutions to address these concerns, because if these challenges remain, students may lose interest in participating in the educational process.

As a result, our findings demonstrated that, contrary to what previous studies claim [28-30], perceived ease of use and perceived utility alone are insufficient to motivate students to adopt E-learning platforms. Our findings imply that the Technology Acceptance Model (TAM) may be enhanced by factoring in various external elements such as university technical circumstances, students' technical circumstances, teachers' teaching style, teachers' technical capabilities, and student-teacher interaction via the platform. If the TAM model can explain the intention to use E-learning platforms in the context in which the platform is used as a complementary tool for the traditional educational process, an improved version of the model could explain the intention to use it in the context of exclusively online learning.

\section{CONCLUSIONS}

The findings and conclusions of this study result in two types of ramifications: practical and theoretical ramifications. On a more practical level, a set of helpful advice for instructors may be presented in order for them to be successful in improving the quality of the educational process in the online environment. The study provides insight into how the educational process unfolded at a period of rapid and numerous changes in La Salle University's higher education system. Thus, it is possible that the quality of the educational process will improve after a longer period of adaptation and familiarization of students and teachers with the online educational set-up, and that students' perceptions of online learning will be more positive, in line with other studies mentioned earlier in this paper.

However, in order for La Salle University's education system to properly and successfully adapt to online teaching and learning, a number of steps must be performed to promote and assist this new style of teaching. In this context, colleges might create training sessions for teachers or programs whose purpose is to improve instructors' performance and the educational process' quality. Due to the size of the aspects held by universities, technical difficulties are still the most difficult to resolve. Universities have undoubtedly made attempts to address these issues and improve the functionality of E-learning systems. Poor internet connections, signal loss, and a lack of sufficient digital equipment continue to be issues for students, particularly those who live in rural regions or come from low-income households. Universities might develop programs to fulfill these demands, making the learning process easier for students who find themselves in these circumstances.

There is a need for concrete actions in the Lasallian higher education system, as well as in other systems [61], to improve and optimize the process of online teaching and learning, such as improving teachers' technical skills, developing training programs to help teachers remodel and adapt their teaching style and the way they interact with students to the online environment, and so on. The literature [64] offers some recommendations for adapting 
the educational process to the online environment, but the adaptations should be done according to the macro setting at the national level, as well as the student profile and study field.

Based on the findings of this study, the researcher argues that the biggest obstacles that La Salle University's higher education system faces today are instructors' adaptability to change and alter students' attitudes toward online learning. Teachers' training programs must be developed to help them adapt to the changes, to help them understand that the future of education in higher education systems is in the online environment, that the system is unlikely to return to its pre-pandemic state, and that online teaching is a new way to interact with students.

Teachers that are open-minded, flexible, and eager to learn became self-taught and attempted to enhance their teaching abilities. However, some teachers are still resistant to learning how to utilize new technologies, and they simply employ the fundamental functionalities of the E-learning platform during their classes. It's also worth noting that in higher education, it's more difficult for professors to admit that they don't know how to utilize specific platform tools, which is why they don't ask for help. However, technological abilities alone are insufficient; teachers must also adapt their teaching approaches to the online environment.

In terms of information processing while online learning, the findings show that it is necessary to use the videoconference function during classes, to balance the number of theory and practical tasks, and to assign students a sufficient number of practical tasks in order for them to avoid spending too many hours in front of the computer for better assimilation of information. To compensate for the absence of connection in the online environment, it is recommended that the assignments require collaboration. As a result, this necessitates not just creativity in conceptualizing and developing projects that encourage collaborative learning, but also technological capabilities in order to construct and deploy systems that increase student engagement. Furthermore, teachers must quickly provide feedback on students' completed tasks, provide support, diversify the tasks assigned to them, use a variety of teaching tools, provide information in multiple formats such as audio, video, text, and devise strategies to pique students' interest and keep them focused during classes.

Another issue would be to change the way teachers connect with students and communicate with them. Students' lack of active learning, critical thinking abilities, and the capacity to argue and voice their opinions, all of which were not fostered or developed by the educational system, are now becoming prominent in the higher education system as part of the online learning process. If professors might create ways to encourage students to gain such abilities in face-to-face classes, it appears that finding new approaches in the online setting is far more challenging. Students have tactics for avoiding tasks that involve critical thinking, discussion, or just expressing a viewpoint, and teachers have little influence over them. Such student excuses include microphone not working, or that the connection is bad, or because there are other people in the room. The researcher does not argue that such situations never exist, but rather that these are the reality that students are frequently using as an excuse to avoid active participation in classes.

Teachers must be present and responsive to students' needs in order to improve their engagement and participation in the educational process which arguably is lower in the online environment. The research also recommends that teachers should come up with solutions so that students can access the information provided during courses such as recording and posting the course on the platform, offering supplementary materials, and if solutions cannot be found, the least teachers can do is be understanding and not sanction students due to such issues. Answers like "there is nothing I can do for you" or "it's your issue" simply serve to demotivate students, raise their dissatisfaction, and raise their chance of dropping out.

\section{ACKNOWLEDGMENTS}

The authors would like to extend their gratitude to the administrators of La Salle University for supporting this endeavor, and for the students who voluntarily participated as respondents.

\section{ETHICAL APPROVAL}

The approval of the Research Ethics Board Committee of La Salle University was gained prior to start of the research.

\section{FUNDING SOURCE}

This research did not receive any outside funding or support

\section{CONFLICTS OF INTERESTS}

The authors declare that there is no conflict of interests 


\section{REFERENCES}

[1] Sobaih, A.E.E.; Hasanein, A.M.; Abu Elnasr, A.E. Responses to COVID-19 in Higher Education: Social Media

[2] Usage for Sustaining Formal Academic Communication in Developing Countries. Sustainability 2020, 12, 6520. [CrossRef]

[3] Ali, W. Online and Remote Learning in Higher Education Institutes: A Necessity in light of COVID-19 Pandemic. High. Educ. Stud. 2020, 10, 16-25. [CrossRef]

[4] Abou El-Seoud, S.; Seddiek, N.; Taj-Eddin, I.; Ghenghesh, P.; Nosseir, A.; El-Khouly, M. E-Learning and

[5] Students' Motivation: A Research Study on the Effect of ELearning on Higher Education. Int. J. Emerg. Technol. Learn. 2014, 9, 689-695. [CrossRef]

[6] Dhawan, S. Online Learning: A Panacea in the Time of COVID-19 Crisis. J. Educ. Technol. Syst. 2020, 49, 5-22. [CrossRef]

[7] Marinoni, G.; Van't Land, H.; Jensen, T. The Impact of COVID-19 on Higher Education around the World. International Association of Universities. Available online: https://www.iau-aiu.net/IMG/pdf/iau_covid19_

and_he_survey_report_final_may_2020.pdf (accessed on 14 August 2020).

[8] Anwar, K.; Adnan, M. Online learning amid the COVID-19 pandemic: Students perspectives. J. Pedagog. Res. 2020, 1, 45-51. [CrossRef]

[9] Suresh, M.; Priya, V.V.; Gayathri, R. Effect of e-learning on academic performance of undergraduate students. Drug Invent. Today 2018, 10, 1797-1800.

[10] Yusuf, N.; Al-Banawi, N. The Impact of Changing Technology: The Case of E-Learning. Contemp. Issues Educ. Res. 2013, 6, 173-180. [CrossRef]

[11] Survey on Online and Distance Learning-Results. Available online: https://www.schooleducationgateway. eu/en/pub/viewpoints/surveys/survey-on-onlineteaching.htm (accessed on 14 August 2020).

[12] Education Responses to COVID-19: Embracing Digital Learning and Online Collaboration.

Available online: http://www.oecd.org/coronavirus/policyresponses/education-responses-to-covid-19embracingdigital-learning-and-online-collaboration-d75eb0e8/ (accessed on 14 August 2020).

[13] Aboagye, E.; Yawson, J.A.; Appiah, K.N. COVID-19 and E-Learning: The Challenges of Students in Tertiary Institutions. Soc. Educ. Res. 2020, 1-8. [CrossRef]

[14] Popovici, A.; Mironov, C. Students' Perception on Using eLearning Technologies. Procedia Soc. Behav. Sci. 2015, 180, 1514-1519. [CrossRef]

[15] Fischer, H.; Heise, L.; Heinz, M.; Moebius, K.; Koehler, T. E-learning trends and hypes in academic teaching. Methodology and findings of a trend study. In Proceedings of the International Association for Development of the Information Society (IADIS) International Conference on Cognition and Exploratory Learning in the Digital Age (CELDA), Porto, Portugal, 25-27 October 2014; pp. 63-69.

[16] Horton, W. E-Learning by Design; Pfeiffer: San Francisco, CA, USA, 2006; ISBN -13.
[17] Engelbrecht, E. Adapting to changing expectations: Postgraduate students' experience of an e-learning tax program. Comput. Educ. 2005, 45, 217-229. [CrossRef]

[18] Koohang, A.; Harman, K. Open Source: A Metaphor for ELearning. Inf. Sci. J. 2005, 8, 75-86. [CrossRef]

[19] Cohen, E.; Nycz, M. Learning Objects and E-Learning: An Informing Science Perspective. Interdiscip. J. E Ski. Lifelong Learn. 2006, 2, 23-34. [CrossRef]

[20] Bezhovski, Z.; Poorani, S. The Evolution of E-Learning and New Trends. Inf. Knowl. Manag. 2016, 6, 50-57.

[21] Lee, B.-C.; Yoon, J.-O.; Lee, I. Learners' acceptance of elearning in South Korea: Theories and results. Comput. Educ. 2009, 53, 1320-1329. [CrossRef]

[22] Sangrà, A.; Vlachopoulos, D.; Cabrera, N. Building an Inclusive Definition of E-Learning: An Approach to the Conceptual Framework. Int. Rev. Res. Open Distance Learn. 2012, 13, 145-159. [CrossRef]

[23] Sangrà, A.; Vlachopoulos, D.; Cabrera, N.; Bravo, S. Towards an Inclusive Definition of e-Learning; eLearn Center UOC: Barcelona, Spain, 2011.

[24] Babu, D.G.S.; Sridevi, D.K. Importance of E-learning in Higher Education: A study. Int. J. Res. Cult. Soc. 2018, 2, 84-88.

[25] Raheem, B.R.; Khan, M.A. The Role of E-learning in Covid-19 Crisis. Int. J. Creat. Res. Thoughts 2020, 8, 31353138.

[26] Oye, N.D.; Salleh, M.; Iahad, N.A. E-Learning Methodologies and Tools. Int. J. Adv. Comput. Sci. Appl. 2012, 3, 48-52. [CrossRef]

[27] Gallie, K.; Joubert, D. Paradigm Shift: From traditional to online education. Stud. Learn. Eval. Innov. Dev. SLEID 2004, 1, 32-36.

[28] Nycz, M.; Cohen, E.B. The basics for understanding elearning. In Principles of Effective Online Teaching; Buzzetto-More, N.A., Ed.; Informing Science Press: Santa Rosa, CA, USA, 2007; pp. 1-17.

[29] Cheung, C.; Cable, J. Eight Principles of Effective Online Teaching: A Decade-Long Lessons Learned in Project Management Education. Proj. Manag. World J. 2017, 6, 116.

[30] Zare, M.; Sarikhani, R.; Salari, M.; Mansouri, V. The impact of E-learning on university students' academic achievement and creativity. J. Tech. Educ. Train. 2016, 8, 25-33.

[31] Almarabeh, T. Students' Perceptions of E-learning at the University of Jordan. Int. J. Emerg. Technol. Learn. IJET. 2014, 9, 31-35. [CrossRef]

[32] Venkatesh, V.; Morris, M.G.; Davis, G.B.; Davis, F.D. User acceptance of information technology: Toward a unified view. MIS Q. 2003, 425-478. [CrossRef]

[33] Vitoria, L.; Mislinawati, M.; Nurmasyitah, N. Students' perceptions on the implementation of e-learning: Helpful or unhelpful? J. Phys. Conf. Ser. 2018, 1088, 1-6. [CrossRef]

[34] Mahdizadeh, H.; Biemans, H.; Mulder, M. Determining factors of the use of e-learning environments by university teachers. Comput. Educ. 2008, 51, 142-154. [CrossRef]

[35] Burac, M.A.P.; Fernandez, J.M.; Cruz, M.M.A.; Cruz, J.D. Assessing the impact of e-learning system of higher 
education institution's instructors and students. IOP Conf. Ser. Mater. Sci. Eng. 2019, 482, 1-8. [CrossRef]

[36] Odit-Dookhan, K. Attitude towards e-learning: The case of mauritian students in public teis. PEOPLE Int. J. Soc. Sci. 2018, 4, 628-643. [CrossRef]

[37] Lochner, L.; Wieser, H.; Waldboth, S.; Mischo-Kelling, M. Combining Traditional Anatomy Lectures with E-Learning Activities: How Do Students Perceive Their Learning Experience? Int. J. Med. Educ. 2016, 7, 69-74. Available online: https://www.ijme.net/archive/7/combining-lectureswith-e-learning-activities/doi:10.5116/ijme.56b5.0369 (accessed on 29 October 2020). [CrossRef]

[38] Alsaaty, F.M.; Carter, E.; Abrahams, D.; Alshameri, F. Traditional Versus Online Learning in Institutions of Higher Education: Minority Business Students' Perceptions. Bus. Manag. Res. 2016, 5, 31. [CrossRef]

[39] Galy, E.; Downey, C.; Johnson, J. The Effect of Using ELearning Tools in Online and Campus-Based Classrooms on Student Performance. J. Inf. Technol. Educ. 2011, 10, 209230. [CrossRef]

[40] Tagoe, M. Students' Perceptions on Incorporating ELearning into Teaching and Learning at the University of Ghana. Int. J. Educ. Dev. Using Inf. Commun. Technol. 2012, 8, 91-103.

[41] Anaraki, F. Developing an Effective and Efficient eLearning Platform. Int. J. Comput. Internet Manag. 2004, 12, 57-63. 